DOI: https://doi.org/10.47405/mjssh.v6i8.939

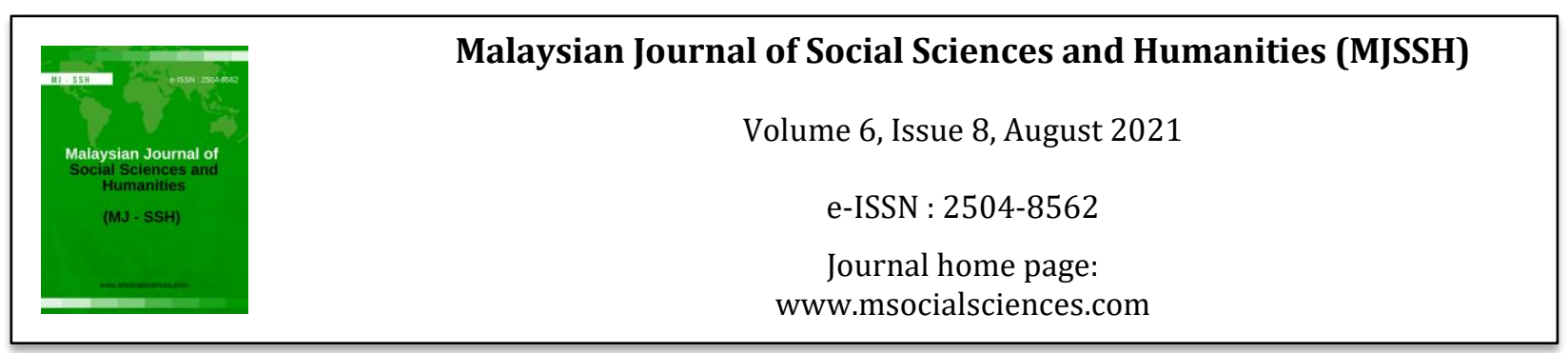

\title{
Penilaian Tahap Kepulihan Penagihan Dadah dalam kalangan Penagih Lelaki yang sedang Menjalani Rawatan dan Pemulihan
}

\author{
Siti Norashida Binti Mohd Rashid¹, Norshahira Binti Osman¹, Lukman Z. Mohamad ${ }^{1}$ \\ ${ }^{1}$ Fakulti Sains Sosial Gunaan, Universiti Sultan Zainal Abidin (UniSZA) \\ Correspondence: Siti Norashida Binti Mohd Rashid (shida194@gmail.com)
}

\begin{abstract}
Abstrak
Kajian psikologikal berkenaan kepulihan ketagihan dadah berkembang dan bertambah secara dinamik selari dengan masalah dadah yang wujud di dunia. Kajian ini berfokus untuk mengenal pasti tahap kepulihan penagih dadah yang menjalani rawatan pemulihan di CCRC Besut secara kuantitatif berdasarkan instrumen DART yang dibina. Seramai 123 penagih dadah yang dirawat di Cure \& Care Rehabilitation Centre (CCRC) di Besut, Terengganu dipilih sebagai responden kajian. Data kajian dianalisis menggunakan analisis deskriptif pada setiap komponen iaitu kebergantungan dadah, kemungkinan relaps dadah, resiliensi dadah dan kekuatan mental klien. Dari segi tahap kepulihan responden di CCRC Besut, kajian ini menunjukkan bahawa $52.03 \%$ responden boleh dibebaskan sepenuhnya, 36.59\% responden boleh dibebaskan sebagai pesakit luar, $8.94 \%$ responden tidak boleh dibebaskan dan perlu diberikan pemantauan, dan $2.44 \%$ responden tidak boleh dibebaskan dan perlu menjalani rawatan secara intensif. Kajian ini membuktikan bahawa instrumen tersebut dapat digunakan untuk mengukur tahap kepulihan penagih yang sedang menjalani rawatan dadah di pusat pemulihan. Kesimpulannya, instrumen DART yang dibina diharapkan dapat membantu kerajaan khususnya CCRC untuk merawat penagih daripada masalah penagihan dadah dengan lebih berkesan di masa depan.
\end{abstract}

Kata kunci: kepulihan ketagihan, kebergantungan dadah, kemungkinan relaps dadah, resiliensi dadah, kekuatan mental klien

\section{Assessment of Drug Addiction Recovery Level Among Male Addicts Undergoing Treatment and Rehabilitation}

\begin{abstract}
Psychological studies on drug addiction recovery are evolving and increasing dynamically in line with the drug problems that exist in the world. This study focused on identifying the level of recovery of drug addicts undergoing rehabilitation treatment at CCRC Besut quantitatively based on the constructed DART instrument. A total of 123 drug addicts treated at the Cure \& Care Rehabilitation Center (CCRC) in Besut, Terengganu were selected as study respondents. Study data were analyzed using descriptive analysis on each component namely drug dependency, drug possible relapse, drug resiliency and mental strength. In terms of the level of recovery of respondents at CCRC Besut, this study showed that $52.03 \%$ of respondents could be fully discharged, $36.59 \%$ of respondents could be discharged as outpatients, $8.94 \%$ of respondents could not be discharged and should be given monitoring, and $2.44 \%$ of respondents could not be discharged and had to undergo intensive treatment. This study proves that the instrument can be used to measure the level of recovery of addicts who are undergoing drug treatment in rehabilitation centers. In conclusion, the DART instrument developed is
\end{abstract}


expected to help the government especially the CCRC to treat addicts from drug addiction problems more effectively in the future.

Keywords: addiction recovery, drug dependence, drug possible relapse, drug resilience, client mental strength

\section{Pengenalan}

Kepulihan dadah adalah bersifat personal dan merupakan proses perubahan individu lebih menumpukan kepada sikap (attitudes), nilai (values), perasaan (feelings), matlamat (goals), kemahiran (skills) dan peranan (roles) (De-Micheli \& Formigoni, 2000; Anthony, 1993). Kepulihan merujuk kepada makna (meaning) dan tujuan (purpose) baharu dalam kehidupan seseorang selepas berjaya mengharungi 'tragedi' penagihan dadah (Deegan, 1988; Miller, 2001). Sekiranya berjaya mengharungi masalah ketagihan, ini bermakna penagih dadah berjaya melepasi peringkat yang sukar dan ini boleh membawa perubahan yang lebih baik dalam kehidupan mereka. Developmental of Recovery (DMR) yang banyak digunakan secara meluas oleh fasiliti yang menyediakan program rawatan kepada penagih dadah. Model ini boleh dibahagikan kepada tahap peralihan (transition stage), stabilisasi (stabilization), peringkat kepulihan awal (early recovery), kepulihan pertengahan (middle recovery), peringkat kepulihan akhir (late recovery), dan akhir sekali tahap pengekalan (maintenance) (Lasimon Matokrem, 2007). Walaupun peranan orientasi institusi dalam pemulihan dadah diketahui sangat penting, terdapat faktor-faktor dalaman dan luaran individu yang dikenal pasti berpengaruh mengganggu proses kepulihan penagih (De-Micheli \& Formigoni, 2000). Kepulihan ketagihan adalah berbeza mengikut modul dan program yang telah ditetapkan untuk setiap pusat pemulihan di Malaysia.

Di Malaysia, model CCRC dirangka secara holistik menggabungkan program pemulihan psikososial dan rawatan klinikal bertujuan untuk mengubah tingkah laku penagihan, memberi kemahiran mencegah relaps, pengetahuan berkaitan kepulihan dan memberi keyakinan kepada klien agar dapat kembali berfungsi seperti yang diharapkan. Ia dirangka khusus berdasarkan keperluan kepulihan klien. Ia mengandungi 10 komponen iaitu kepulihan awalan, pencegahan penagihan semula, sokongan sosial, agama \& kerohanian, bimbingan \& kaunseling, integrasi masyarakat, latihan dan kemahiran vokasional, sukan dan riadah, rawatan dan kesihatan, latihan kawad dan fizikal (AADK, 2015). Instrumen Ujian Kepulihan Penagihan Dadah (DART) adalah untuk mengukur tahap kepulihan ketagihan dadah di kalangan penagih berdasarkan konteks persekitaran Malaysia. Kajian ini dapat membantu Agensi Anti Dadah Kebangsaan (AADK) dan Pusat Pemulihan Dadah Swasta untuk mengembangkan instrumen dan menganalisis tahap kepulihan ketagihan pada penagih dadah. Kajian ini meliputi empat komponen iaitu kebergantungan dadah, kemungkinan relaps dadah, resiliensi dadah dan kekuatan mental klien berdasarkan kepada kajian sebelumnya oleh pengkaji sebelum ini.

\section{Literatur Kajian}

Kebergantungan dadah sangat berkait rapat dengan psikologi (WHO, 1964). Individu yang terlibat dalam situasi ini sentiasa gembira dan berada dalam keadaan selesa menikmati kepuasan pengambilan dadah yang berterusan. Keadaan mental adalah salah satu bahagian penggunaan dadah yang paling terjejas manakala fizikal adalah faktor yang sangat kuat dalam bergantung kepada penggunaan dadah yang berterusan atau relaps. Terdapat dua bentuk kebergantungan kepada dadah, iaitu pergantungan fizikal dan psikologi (Leventhal et al., 2008). Dalam kajian ini kebergantungan kepada dadah diukur oleh faktor dalaman dan faktor luaran. Faktor Dalaman adalah faktor dalaman seseorang individu sejak mereka berada di dalam kandungan sehingga lahir. Faktor dalaman adalah sifat yang wujud dan diwarisi oleh seseorang individu yang dapat mengawal perkembangan manusia. Dalam kajian ini, faktor dalaman merangkumi perkembangan individu dari segi keperibadian dan persekitaran. Sebaliknya, menurut Sharma (1995), menyimpulkan bahawa terdapat bukti untuk keperibadian ketagihan secara terperinci. 
Namun, walaupun penagih cenderung mempunyai sifat keperibadian ketagihan, ketagihan terhadap dadah atau alkohol tidak menyebabkan perkembangan keperibadian ketagihan. Teori yang menjelaskan hubungan antara keperibadian dan kebergantungan dadah adalah luas serta penting bagi rawatan yang berkesan dan menyeluruh bagi mereka yang mempunyai masalah dadah dan alkohol (Moody, 2003). Faktor luaran seseorang individu adalah melalui pengalaman dan persekitaran individu. Persekitaran merujuk kepada semua pengalaman yang harus dilalui seseorang tanpa mengira situasi di rumah, jiran, komuniti atau di mana sahaja berada. Contohnya, amalan keluarga boleh dipelajari di rumah dan dibawa ke luar. Tambahan pula, rakan sebaya juga dapat mempengaruhi gaya hidup dan hubungan seseorang individu. Kebergantungan dadah sangat berkaitan dengan faktor dalaman dan luaran dalam pemulihan ketagihan dadah.

Relaps berlaku kerana seseorang itu tidak dapat hidup dengan damai tanpa dadah. Kajian terdahulu menunjukkan bahawa terdapat dua cara untuk melihat keadaan berlakunya relaps. Relaps boleh ditafsirkan sebagai penggunaan dadah untuk jangka waktu tertentu sebagai pengembalian ke tahap asas pra-rawatan atau sebagai pengembalian ke tahap penggunaan dadah yang menetapkan kriteria yang ditetapkan untuk kuantiti atau jangka masa penggunaan dadah (APA, 1994). Oleh itu, dalam kajian ini kemungkinan relaps dadah diukur melalui emosi, kawalan diri, efikasi diri, dan keyakinan diri. Emosi negatif adalah antara faktor yang menyumbang kepada bekas penagih dadah kepada tingkah laku relaps (Melemis, 2015; Fauziah et al., 2018; Scozelli, 1987; Sun, 2007, Fernandez-Hermida et al., 2002; Hammer-bacher \& Lyvers, 2006). Faktor relaps lain efikasi diri, ditakrifkan sebagai tahap di mana seseorang individu merasa yakin dan mampu melakukan tingkah laku tertentu dalam konteks situasi tertentu (Fauziah et al., 2009; Cheung et al., 2003; Lozano et al., 2006). Penagih dadah mendapat rawatan dan pemulihan pusat pemulihan dadah mempunyai keadaan psikologi yang buruk (Mahmood; 1995). Ia juga dijelaskan bahawa keyakinan diri dapat mengurangkan kebergantungan dan dengan itu membantu mereka pulih dari kesan dadah (Ruhani et al., 2012; Lily et al., 2004; Fauziah et al., 2017).

Ketahanan adalah berasal Latin yang merujuk kepada keadaan anjal dan elastik. Ketahanan telah didefinisikan sebagai kemampuan untuk menahan tekanan. Individu yang berterusan dalam kemampuannya boleh disebut tabah, tidak lemah atau tidak kalah (Werner \& Smith, 1982). Terminologi ketahanan secara amnya merujuk kepada kemampuan untuk bangkit semula atau ketangkasan dari sebarang ketahanan, tekanan, atau trauma, dan berjaya mengatasi dan menyesuaikan diri dengan situasi yang sukar (Glantz et al., 1999). Ketahanan adalah kualiti seseorang dari segi kemampuannya mengatasi penderitaan (Connor \& Davidson, 2003). Ketahanan adalah untuk mendapatkan kemampuan individu untuk bertahan atau menyesuaikan situasi yang menyebabkan tekanan dan penderitaan dalam hidup mereka. Oleh itu, berdasarkan pernyataan di atas, ketahanan adalah kemampuan individu untuk menyesuaikan keadaan mereka dengan memperlakukan mereka dengan cara yang lebih sihat dan lebih produktif untuk memperbaiki diri agar dapat mengatasi tekanan kehidupan seharian yang mereka alami. Untuk ketahanan dadah komponen diukur dengan ketahanan diri, kemampuan diri dan kecekapan. Ciri keperibadian yang dapat dikategorikan sebagai daya tahan adalah kekuatan dalam diri (Buckingham et al., 2001; Peterson \& Seligman, 2004). Satu kajian yang dilakukan oleh, program pemulihan dadah atau spiritual sebenarnya membantu mengembangkan ketagihan yang kuat dan ciri-ciri peribadi penagih. Keupayaan bermaksud kecerdasan, kesediaan, kemampuan, kecekapan, kekuatan mental dan tenaga. Ketahanan adalah kemampuan untuk bertindak balas positif terhadap tekanan kesukaran (kegagalan, kemunduran, kerugian,) secara berterusan. Kompetensi adalah kemampuan, pengetahuan dan kemahiran untuk melakukan sesuatu dengan cekap dan berjaya. Kompetensi membincangkan hubungan antara kecekapan sosial dalam proses ketahanan. Ketahanan adalah salah satu yang meningkatkan kemampuan seseorang untuk berjaya dalam cabaran hidup dan berisiko tinggi (Rutter, 1965).

Kekuatan mental merupakan kemampuan minda seseorang untuk terus berusaha mencapai tujuan atau perubahan diri seseorang tanpa mengira halangan dalam hidup mereka. Kekuatan mental adalah kemahiran yang dapat dikembangkan oleh seseorang individu dengan menjadikan kekuatan mental sebagai amalan dalam kehidupan seseorang. Setiap keputusan yang dibuat oleh individu melibatkan perasaan dan fikiran yang membolehkan individu itu mengembangkan kekuatan mental. Perkara yang paling penting untuk membina kekuatan mental adalah memperoleh kebijaksanaan, berinteraksi dengan orang lain dan berfikir secara berbeza. Kebijaksanaan adalah salah satu ciri membina atau 
mengembangkan kekuatan mental mengikut tahap pengetahuan diri. Seorang individu tidak boleh hidup tanpa bergantung pada orang lain. Sekiranya seseorang individu tidak bergantung pada orang lain, maka mereka dapat mengenal pasti kesejahteraan mereka sendiri dan memperkuat ketajaman mental yang ada untuk menguatkan kekuatan mental mereka dengan menjaga diri tanpa bergantung pada orang lain. Dalam kajian ini kekuatan mental diukur oleh harga diri, autonomi dan tujuan hidup.

Harga diri merupakan sikap sendiri, baik positif dan negatif (Rosenberg, 1965; Coopersmith, 2002). Harga diri adalah harga diri individu seperti yang dibuktikan olehnya. Autonomi merujuk kepada autonomi biologi, autonomi mental, emosi dan psikologi dan sub ini berkaitan dengan kekuatan mental. Menurut Rovee-Collier (1999), autonomi mental di mana perspektif yang benar-benar cerdas mesti bersifat autonomi dalam dirinya sendiri. Nyatakan bahawa kepuasan hidup seseorang merujuk kepada penerimaan seseorang terhadap keadaan hidupnya dan sejauh mana seseorang mencapai apa yang ingin dicapai (Sousa \& Lyubomirsky, 2001). Menurut Lent (2004), juga kepuasan hidup adalah tahap kebahagiaan seseorang untuk diri mereka sendiri dan kehidupan mereka. Ketiga-tiga sub komponen sangat berkaitan dengan mengetahui tahap kekuatan mental penagih dadah.

\section{Metod Kajian}

Kaedah kajian adalah tinjauan kuantitatif terhadap 123 penagih yang dirawat di Cure \& Care Rehabilitation Centre (CCRC) pada tahun 2019. Penyelidik mengambil masa kira-kira satu hari untuk menyelesaikan pengumpulan data dan setiap orang memerlukan sekitar 60 minit untuk menyelesaikan soal selidik. Prosedur ini membantu pengumpulan soal selidik dan disusun pada akhir November 2019. Data dikumpulkan dari pusat pemulihan dadah di Besut Terengganu proses pengumpulan data dilakukan sebanyak dua kali yang mana kali pertama adalah dilakukan untuk melakukan kajian rintis manakala kali kedua dilakukan kutipan data yang sebenar secara keseluruhan responden di pusat pemulihan tersebut. Komponennya adalah kebergantungan dadah, kemungkinan relaps dadah, resiliensi dadah dan kekuatan mental klien. Keempat-empat komponen tersebut diukur dengan menggunakan soal selidik untuk mengenal pasti tahap kepulihan dadah penghuni yang menjalani rawatan pemulihan di CCRC Besut berdasarkan instrumen yang dibina. Instrumen ini juga melalui beberapa proses keabsahan kandungan, seperti menentukan definisi setiap kandungan dan berjumpa dengan pakar kandungan yang merupakan kepakaran dalam bidang kajian yang berkaitan (Rico et al., 2012; Krosnick et al., 2010; Rowley, 2014). Analisis data yang digunakan untuk mengenal pasti tahap kepulihan penagihan dadah adalah analisis deskriptif pada setiap komponen instrumen DART.

\section{Dapatan Kajian}

\section{Profil Responden}

Ciri-ciri profil responden diambil kira berdasarkan pelbagai pemboleh ubah atau ciri-ciri yang menentukan profil responden. Profil responden telah dibahagikan kepada beberapa pemboleh ubah iaitu tempoh berada di pusat pemulihan, umur responden semasa kajian, umur mula mengambil dadah, tempoh responden mengambil dadah, tahap pendidikan, status perkahwinan, keluarga yang membesarkan responden, pekerjaan responden, tempat tinggal responden, alasan responden menggunakan dadah, jenis dadah yang pernah diambil oleh responden dan responden kajian menjalani ujian psikologi yang pernah dilakukan berkaitan dengan pemulihan. Menurut tempoh responden berada di pusat pemulihan dan jagaan dapat dilihat bahawa tempoh antara 0-6 bulan adalah $46.30 \%$ manakala 7-12 bulan adalah 48.80 \% dan 13-18 bulan adalah 4.90\%, sebagaimana ditunjukkan dalam Jadual 1. Jadual 2 menyatakan usia responden semasa kajian yang berada di pusat pemulihan dapat diketengahkan bahawa $36.60 \%$ berumur antara 26-30 tahun manakala 18.70 tahun. $8.90 \%$ adalah peratusan untuk usia 46-50 tahun dan yang terakhir adalah 0.80\% antara usia 51-55 tahun. 
DOI: https://doi.org/10.47405/mjssh.v6i8.939

Jadual 1: Tempoh Berada Di Pusat Pemulihan

\begin{tabular}{llc}
\hline & $f$ & $\%$ \\
\hline 0-6bulan & 57 & 46.30 \\
7-12 bulan & 60 & 48.80 \\
13-18 bulan & 6 & 4.90 \\
Jumlah & $\mathbf{1 2 3}$ & $\mathbf{1 0 0 . 0 0}$ \\
\hline
\end{tabular}

Jadual 2: Umur responden semasa kajian

\begin{tabular}{lcc}
\hline & $\boldsymbol{f}$ & $\boldsymbol{\%}$ \\
\hline $26-30$ tahun & 45 & 36.60 \\
$31-35$ tahun & 23 & 18.70 \\
$36-40$ tahun & 28 & 22.80 \\
$41-45$ tahun & 15 & 12.20 \\
$46-50$ tahun & 11 & 8.90 \\
51-55 tahun & 1 & 0.80 \\
Jumlah & $\mathbf{1 2 3}$ & $\mathbf{1 0 0 . 0 0}$ \\
\hline
\end{tabular}

Di samping itu, dapat dilihat dari Jadual 3 bahawa usia responden mula mengambil dadah bermula dari 10 tahun ke bawah adalah $8.90 \%$ responden kajian yang mengambil dadah, sementara peratusan $11.40 \%$ adalah antara umur 11-15 tahun , 26. 00\% antara usia pengambilan dadah 16- 20 tahun, $25.20 \%$ adalah peratusan antara usia 21-25 tahun, $15.40 \%$ antara usia 26-30 tahun, $7.3 \%$ antara usia 31-35 tahun, $4.10 \%$ antara usia 36-40 tahun, $0.80 \%$ antara usia 41-45 tahun sementara yang terakhir adalah $0.80 \%$ yang merupakan peratusan bagi usia 46-50 tahun yang mula mengambil dadah. Seterusnya Jadual 4 adalah menerangkan tentang tempoh responden mengambil dadah dari usia 12 tahun ke bawah iaitu peratusan responden yang menyumbang untuk soalan ini adalah 12 tahun ke bawah sebanyak $8.00 \%, 1-3$ tahun adalah $10.60 \%$, 4-6 tahun adalah $22.80 \%$, 7-9 tahun adalah $10.60 \%$, 10-12 tahun adalah $27.60 \%, 13-15$ tahun adalah 6.50\%, 16-18 tahun adalah 3.30\%, 19-21 tahun adalah $8.10 \%, 22-24$ tahun adalah $4.10 \%, 25-27$ tahun adalah $1.60 \%, 28-30$ tahun adalah 1.60\%, 31-33 tahun adalah $0.80 \%, 34-36$ tahun adalah $0.80 \%, 37-39$ tahun adalah $0.80 \%$ dan yang terakhir adalah $40-43$ tahun dengan peratusan $0.80 \%$.

Jadual 3: Umur responden mula mengambil dadah

\begin{tabular}{lcc}
\hline & $\boldsymbol{f}$ & $\boldsymbol{\%}$ \\
\hline 10 tahun ke bawah & 11 & 8.90 \\
$11-15$ tahun & 14 & 11.40 \\
$16-20$ tahun & 32 & 26.00 \\
$21-25$ tahun & 31 & 25.20 \\
26-30 tahun & 19 & 15.40 \\
$31-35$ tahun & 9 & 7.30 \\
36-40 tahun & 5 & 4.10 \\
41-45 tahun & 1 & 0.80 \\
46-50 tahun & 1 & 0.80 \\
Jumlah & $\mathbf{1 2 3}$ & $\mathbf{1 0 0 . 0 0}$ \\
\hline
\end{tabular}

Jadual 4: Tempoh responden mengambil dadah

\begin{tabular}{lcc}
\hline & $\boldsymbol{f}$ & $\%$ \\
\hline 12 bulan ke bawah & 1 & 0.80 \\
$1-3$ tahun & 13 & 10.60 \\
$4-6$ tahun & 28 & 22.80 \\
$7-9$ tahun & 13 & 10.60 \\
$10-12$ tahun & 34 & 27.60 \\
\hline
\end{tabular}


DOI: https://doi.org/10.47405/mjssh.v6i8.939

\begin{tabular}{lcc}
\hline 13-15 tahun & 8 & 6.50 \\
16-18 tahun & 4 & 3.30 \\
19-21 tahun & 10 & 8.10 \\
$22-24$ tahun & 5 & 4.10 \\
$25-27$ tahun & 2 & 1.60 \\
$28-30$ tahun & 2 & 1.60 \\
$31-33$ tahun & 1 & 0.80 \\
$34-36$ tahun & 1 & 0.80 \\
$37-39$ tahun & 1 & 0.80 \\
Jumlah & $\mathbf{1 2 3}$ & $\mathbf{1 0 0 . 0 0}$ \\
\hline
\end{tabular}

Di samping itu, dapat dilihat dari Jadual 5 di bawah bahawa $3.30 \%$ responden tidak bersekolah sementara $7.30 \%$ responden mempunyai pendidikan sekolah rendah. $74.80 \%$ responden telah mencapai pendidikan sekolah menengah dan merupakan peratusan yang tinggi dalam tahap pendidikan. Secara kolektif, $14.60 \%$ responden kajian telah mencapai pendidikan hingga ke peringkat kolej/Universiti. Seterusnya adalah status perkahwinan, status perkahwinan membuktikan bahawa peratusan sebanyak 56.10\% adalah responden bujang, $30.90 \%$ adalah responden yang telah berkahwin dan $13.00 \%$ adalah duda. Mengikut analisis ini responden yang dibesarkan oleh ibu bapa kandung peratusan sebanyak $87.00 \%$, ibu tiri ayah kandung peratusan sebanyak 0.80\%. ibu tunggal (kematian suami) peratusan adalah $1.60 \%$, ibu tunggal (diceraikan suami) adalah sebanyak $7.30 \%$, bapa tunggal (kematian isteri) adalah sebanyak $1.60 \%$, bapa tunggal (bercerai dengan isteri) adalah sebanyak $0.80 \%$ manakala ibu bapa angkat adalah $0.80 \%$. Berdasarkan Jadual 8 akan memperjelaskan pekerjaan responden iaitu tidak bekerja adalah $7.30 \%$, bekerja sendiri sebanyak $56.90 \%$ iaitu peratusan yang lebih tinggi, pekerja kerajaan sebanyak $8.10 \%$, manakala yang terakhir adalah pekerja swasta sebanyak $27.60 \%$.

Jadual 5: Tahap Pendidikan

\begin{tabular}{lcc}
\hline & $\boldsymbol{f}$ & $\boldsymbol{\%}$ \\
\hline Tidak bersekolah & 4 & 3.30 \\
Sekolah rendah & 9 & 7.30 \\
Sekolah menegah & 92 & 74.80 \\
Kolej/Universiti & 18 & 14.60 \\
Jumlah & $\mathbf{1 2 3}$ & $\mathbf{1 0 0 . 0 0}$ \\
\hline
\end{tabular}

Jadual 6: Status Perkahwinan

\begin{tabular}{lcc}
\hline & $\boldsymbol{f}$ & $\%$ \\
\hline Bujang & 69 & 56.10 \\
Berkahwin & 38 & 30.90 \\
Duda & 16 & 13.00 \\
Jumlah & $\mathbf{1 2 3}$ & $\mathbf{1 0 0 . 0 0}$ \\
\hline
\end{tabular}

Jadual 7: Keluarga Yang Membesarkan Responden

\begin{tabular}{lcc}
\hline & $\boldsymbol{f}$ & $\%$ \\
\hline Ibu bapa kandung & 107 & 87.00 \\
Ibu tiri ayah kandung & 1 & 0.80 \\
Ibu tunggal (Kematian suami) & 2 & 1.60 \\
Ibu tunggal ( Diceraikan suami) & 9 & 7.30 \\
Bapa tunggal ( Kematian isteri) & 2 & 1.60 \\
Bapa tunggal ( Bercerai dengan isteri) & 1 & 0.80 \\
Ibu bapa angkat & 1 & 0.80 \\
Jumlah & $\mathbf{1 2 3}$ & $\mathbf{1 0 0 . 0 0}$ \\
\hline
\end{tabular}


DOI: https://doi.org/10.47405/mjssh.v6i8.939

Jadual 8: Pekerjaan Responden

\begin{tabular}{lcc}
\hline & $\boldsymbol{f}$ & $\%$ \\
Tidak bekerja & 9 & 7.30 \\
Bekerja sendiri & 70 & 56.90 \\
Pekerja kerajaan & 10 & 8.10 \\
Pekerja swasta & 34 & 27.60 \\
Jumlah & $\mathbf{1 2 3}$ & $\mathbf{1 0 0 . 0 0}$ \\
\hline
\end{tabular}

Jadual 9 juga menerangkan peratusan tempat tinggal responden membuktikan peratusan responden yang berasal dari bandar sebanyak $16.30 \%$, manakala responden yang berasal dari pekan sebanyak $8.90 \%$, responden tinggal di kampung lebih tinggi peratusan iaitu sebanyak $74.80 \%$. Seterusnya adalah alasan responden terjebak adalah seperti Jadual 10 menerangkan pengaruh kawan sebanyak $22.90 \%$, perasaan ingin tahu peratusan adalah sebanyak $31.90 \%$ manakala keseronokan/hiburan, peratusannya adalah $13.90 \%$, tekanan perasaan adalah pula adalah sebanyak $8.30 \%$, berjaga malam pula sebanyak $2.10 \%$, rangsangan seks adalah sebanyak $3.50 \%$, manakala tenaga tambahan untuk kerja membuktikan peratusan sebanyak $17.40 \%$. Di samping itu, peratusan yang ditunjukkan di Jadual 11 adalah jenis dadah yang pernah di ambil oleh responden kajian iaitu heroin peratusannya adalah $17.60 \%$, morfin sebanyak $7.60 \%$ ubat batuk (codein) sebanyak $4.80 \%$, ganja pula sebanyak $8.10 \%$, amfetamin pula sebanyak $1.00 \%$, syabu/ice/batu adalah sebanyak $27.60 \%$, pil kuda $19.00 \%$, pil ecstacy sebanyak $1.00 \%$ erimin 5 pula adalah sebanyak $4.30 \%$, Rohynol sebanyak $0.50 \%$, air ketum sebanyak $7.10 \%$ dan Gam $1.40 \%$. Berdasarkan Jadual 12, responden kajian menjalani ujian psikologi yang berkaitan dengan pemulihan dadah iaitu responden yang tidak pernah melakukan ujian psikologi peratusan adalah lebih tinggi iaitu sebanyak $70.70 \%$ dan $29.30 \%$ adalah responden yang tidak pernah menjalani ujian psikologi.

Jadual 9: Tempat Tinggal Responden

\begin{tabular}{lcc}
\hline & $\boldsymbol{f}$ & $\%$ \\
\hline Bandar & 20 & 16.30 \\
Pekan & 11 & 8.90 \\
Kampung & 92 & 74.80 \\
Jumlah & $\mathbf{1 2 3}$ & $\mathbf{1 0 0 . 0 0}$ \\
\hline
\end{tabular}

Jadual 10: Alasan Responden Menggunakan Dadah

\begin{tabular}{lcc}
\hline & $\boldsymbol{f}$ & $\%$ \\
\hline Pengaruh kawan & 33 & 22.90 \\
Perasaan ingin tahu & 46 & 31.90 \\
Keseronokan hiburan & 20 & 13.90 \\
Tekanan perasaan & 12 & 8.30 \\
Berjaga malam & 3 & 2.10 \\
Rangsangan seks & 5 & 3.50 \\
Tenaga tambahan untuk kerja & 25 & 17.40 \\
Jumlah & $\mathbf{1 4 4}$ & $\mathbf{1 0 0 . 0 0}$ \\
\hline
\end{tabular}

Jadual 11: Jenis Dadah Yang Pernah di Ambil Oleh Responden

\begin{tabular}{lcc}
\hline & $f$ & $\%$ \\
\hline Heroin & 37 & 17.60 \\
Morfin & 16 & 7.60 \\
Ubat batuk (Codein) & 10 & 4.80 \\
Ganja & 17 & 8.10 \\
Amfetamin & 2 & 1.00 \\
Syabu/Ice/batu & 58 & 27.60 \\
Pil Kuda & 40 & 19.00 \\
Pil Ecstacy & 2 & 1.00 \\
Erimin 5 & 9 & 4.30 \\
\hline
\end{tabular}


DOI: https://doi.org/10.47405/mjssh.v6i8.939

\begin{tabular}{lcc}
\hline Rohynol & 1 & 0.50 \\
Air Ketum & 15 & 7.10 \\
Gam & 3 & 1.40 \\
Jumlah & $\mathbf{2 1 0}$ & $\mathbf{1 0 0 . 0 0}$ \\
\hline
\end{tabular}

Jadual 12: Responden Kajian Menjalani Ujian Psikologi Berkaitan Pemulihan Dadah

\begin{tabular}{|c|c|c|}
\hline & $f$ & $\%$ \\
\hline Pernah & 36 & 29.30 \\
\hline Tidak Pernah & 87 & 70.70 \\
\hline Jumlah & 123 & 100.00 \\
\hline
\end{tabular}

\section{Hasil Analisis Deskriptif}

Berdasarkan Jadual 13, 74 responden kajian atau 60.16\% menunjukkan tiada keinginan untuk bergantung kepada dadah dan responden ini diberi kaunseling jika perlu. Seterusnya, 41 orang responden iaitu 33.33\% adalah masih rendah terhadap kebergantungan kepada dadah, responden masih ada sedikit perasaan untuk bergantung semula kepada dadah. Jumlah peratusan responden ini menunjukkan responden perlu diberikan kaunseling dan sokongan secara berterusan untuk bebas daripada bergantung kepada dadah. Sebanyak $4.07 \%$ iaitu 5 responden kajian berada di peringkat sederhana membuktikan bahawa responden tidak dapat melupakan dadah dan masih ingin bergantung kepada dadah. Oleh itu, pada peringkat ini responden kajian ini perlu diberikan kaunseling dan rawatan pemulihan secara berterusan untuk bebas daripada bergantung kepada dadah. Manakala peratusan terendah iaitu $2.44 \%$ bersamaan 3 responden kajian tahap kebergantungan kepada dadah adalah tinggi, responden tidak dapat melupakan dadah sepenuhnya dan akan bergantung semula kepada dadah selepas rawatan.

Jadual 13: Frekuensi Dan Peratusan Responden Terhadap Komponen Kebergantungan Dadah

\begin{tabular}{lcc}
\hline Skor keseluruhan & $\boldsymbol{f}$ & \% \\
\hline Tidak bergantung & 74 & 60.16 \\
Rendah & 41 & 33.33 \\
Sederhana & 5 & 4.07 \\
Tinggi & 3 & 2.44 \\
Jumlah & $\mathbf{1 2 3}$ & $\mathbf{1 0 0 . 0 0}$ \\
\hline
\end{tabular}

Berdasarkan Jadual 14, seramai 76 responden kajian atau 61.78\% adalah tidak relaps kepada dadah dan responden kajian tidak mempunyai tanda-tanda relaps kepada dadah. Ini menunjukkan bahawa responden ini diberi kaunseling jika perlu sahaja berbanding dengan responden-responden yang lain. Seterusnya, 32 orang responden kajian iaitu sebanyak $26.02 \%$ adalah masih di peringkat rendah yang mana responden dijangka sedikit relaps kepada dadah. Jumlah peratusan responden ini perlu diberikan kaunseling dan sokongan secara berterusan untuk tidak relaps kepada dadah. Sebanyak $8.13 \%$ iaitu 10 responden kajian berada di peringkat sederhana relaps kepada dadah dan responden tidak dapat melupakan dadah dan masih ingin relaps kepada dadah pada peringkat ini. Oleh itu, responden kajian ini perlu diberikan kaunseling dan rawatan pemulihan secara berterusan daripada relaps kepada dadah. Manakala peratusan terendah iaitu $4.07 \%$ bersamaan 5 responden kajian tahap relaps kepada dadah adalah tinggi, responden tidak dapat melupakan dadah sepenuhnya dan akan relaps semula kepada dadah selepas rawatan. Pada peringkat ini klien masih lagi perlu diberikan perhatian dan rawatan secara berterusan untuk bebas daripada relaps kepada dadah. 
DOI: https://doi.org/10.47405/mjssh.v6i8.939

Jadual 14: Frekuensi Dan Peratusan Responden Terhadap Komponen

Kemungkinan Relaps Dadah

\begin{tabular}{lll}
\hline Skor Keseluruhan & $\boldsymbol{f}$ & \% \\
\hline Tidak Relaps & 76 & 61.78 \\
Rendah & 32 & 26.02 \\
Sederhana & 10 & 8.13 \\
Tinggi & 5 & 4.07 \\
Jumlah & 123 & 100.00 \\
\hline
\end{tabular}

Berdasarkan Jadual 15, seramai 68 orang responden kajian atau 55. 28\% adalah baik dan responden mempunyai resilien yang baik kepada dadah. Ini menunjukkan bahawa responden ini diberi kaunseling jika perlu berbanding dengan responden-responden yang lain. Seterusnya, 42 orang responden kajian iaitu sebanyak $34.15 \%$ adalah masih rendah dalam resilien kepada dadah dan menjelaskan bahawa responden mempunyai resilien yang kurang terhadap dadah. Jumlah peratusan responden ini perlu diberikan kaunseling dan sokongan secara berterusan untuk tidak kembali kepada dadah. Sebanyak $7.32 \%$ iaitu 9 responden kajian berada di peringkat sederhana mempunyai resilian yang lemah dan masih ingin kepada dadah. Responden kajian perlu diberikan kaunseling dan rawatan pemulihan secara berterusan daripada kembali kepada dadah. Manakala peratusan terendah iaitu $3.25 \%$ bersamaan 4 responden kajian tahap resilien kepada dadah adalah tinggi, responden masih lagi perlu diberikan perhatian dan rawatan secara berterusan untuk bebas daripada dadah.

Jadual 15: Frekuensi Dan Peratusan Responden Terhadap Komponen Resiliensi Dadah

\begin{tabular}{lcc}
\hline Skor keseluruhan & $\boldsymbol{f}$ & $\boldsymbol{\%}$ \\
\hline Baik & 68 & 55.28 \\
Rendah & 42 & 34.15 \\
Sederhana & 9 & 7.32 \\
Tinggi & 4 & 3.25 \\
Jumlah & $\mathbf{1 2 3}$ & $\mathbf{1 0 0 . 0 0}$ \\
\hline
\end{tabular}

Berdasarkan Jadual 16, seramai 61 orang responden kajian atau $49.59 \%$ adalah mempunyai kekuatan mental tahap yang baik. Responden mempunyai kekuatan mental yang baik dan dapat bertahan daripada dadah. Responden dapat dibebaskan pada peringkat ini. Seterusnya, 40 orang responden kajian iaitu sebanyak $32.52 \%$ adalah masih rendah klien tidak mempunyai kekuatan mental sepenuhnya dan masih mengingati dadah. Jumlah peratusan responden ini perlu diberikan kaunseling dan sokongan secara berterusan untuk tidak mengingati dadah. Sebanyak $14.63 \%$ iaitu 18 responden kajian berada di peringkat sederhana responden mempunyai kekuatan mental yang lemah dan masih ingin kepada dadah pada peringkat ini. Oleh itu, responden kajian ini perlu diberikan kaunseling dan rawatan pemulihan secara berterusan untuk bebas daripada bergantung kepada dadah. Manakala peratusan terendah iaitu $3.25 \%$ bersamaan 4 responden kajian, responden mempunyai kekuatan mental yang sangat lemah dan akan kembali semula kepada dadah selepas rawatan. Pada peringkat ini responden masih lagi perlu diberikan perhatian dan rawatan secara berterusan untuk bebas daripada dadah.

Jadual 16 : Frekuensi Dan Peratusan Responden Terhadap Komponen Kekuatan Mental Klien

\begin{tabular}{lcc}
\hline Skor Keseluruhan & $\boldsymbol{f}$ & $\boldsymbol{\%}$ \\
\hline Baik & 61 & 49.59 \\
Rendah & 40 & 32.52 \\
Sederhana & 18 & 14.63 \\
Tinggi & 4 & 3.25 \\
Jumlah & $\mathbf{1 2 3}$ & $\mathbf{1 0 0 . 0 0}$ \\
\hline
\end{tabular}

Berdasarkan Jadual 17, seramai 64 orang responden kajian atau 52.03\% adalah responden dibebaskan sepenuhnya dari CCRC. Seterusnya, 45 orang responden dibebaskan sebagai pesakit luar iaitu 
sebanyak 36.59\%. Sebanyak $8.94 \%$ iaitu bersamaan 11 responden kajian tidak boleh dibebaskan dan perlu diberikan pemantauan. Manakala peratusan terendah iaitu $2.44 \%$ bersamaan 3 responden kajian tidak boleh dibebaskan dan perlu menjalani rawatan secara intensif.

Jadual 17: Tahap Kepulihan Penagihan Dadah Responden Di CCRC

\begin{tabular}{|c|c|c|}
\hline Huraian & $f$ & $(\%)$ \\
\hline Responden dibebaskan sepenuhnya & 64 & 52.03 \\
\hline $\begin{array}{l}\text { Responden dibebaskan sebagai pesakit } \\
\text { luar }\end{array}$ & 45 & 36.59 \\
\hline $\begin{array}{l}\text { Responden tidak boleh dibebaskan dan } \\
\text { perlu diberikan pemantauan }\end{array}$ & 11 & 8.94 \\
\hline $\begin{array}{l}\text { Responden tidak boleh dibebaskan dan } \\
\text { perlu menjalani rawatan secara intensif }\end{array}$ & 3 & 2.44 \\
\hline Jumlah & 123 & 100.00 \\
\hline
\end{tabular}

\section{Perbincangan Kajian}

Bukti penyelidikan ini untuk menunjukkan bahawa pemulihan ketagihan dadah bukanlah masalah kecil. Ini adalah masalah serius dan ancaman besar bagi negara. Terlibat dalam penyalahgunaan dadah bukanlah jalan keluar untuk masalah. Walau bagaimanapun, sebilangan penagih dalam kajian ini berasal dari latar belakang yang secara tepat dapat digambarkan sebagai orang yang kurang berkemampuan.

i. Mereka menyalahgunakan dadah pada usia yang lebih tua, terbukti dalam kajian ini usia 16 tahun dan 20 tahun adalah penagih usia paling tinggi mula mengambil dadah.

ii. Mereka menghadapi masalah pendidikan di sekolah menengah.

iii. Tidak ada rasa tanggungjawab yang menyebabkan mereka membuat masalah dalam diri mereka (penagih yang lebih tinggi adalah penagih tunggal).

iv. Mereka mempunyai masalah hubungan dengan ibu bapa mereka.

v. Mereka berasal dari keluarga yang tidak berfungsi, terutamanya dari keluarga yang bermasalah, masalah keluarga yang pelbagai, pengabaian emosi dan fizikal ibu bapa, dan keganasan rumah tangga.

vi. Mereka mempunyai sejarah yang datang dari kota yang memudahkan mereka mendapatkan dadah.

vii. Mereka mengalami rasa ingin tahu untuk menggunakan dadah dalam diri mereka.

viii. Jenis-jenis dadah mudah didapati menjadikannya mudah untuk mendapatkannya

ix. Tidak pernah menjalani ujian psikologi yang berkaitan dengan pemulihan dadah menyebabkan mereka tidak mempunyai motivasi untuk berhenti daripada dadah.

Selain itu, Berdasarkan komponen kebergantungan dadah, 74 responden kajian atau $60.16 \%$ menunjukkan tiada keinginan untuk bergantung kepada dadah dan responden ini diberi kaunseling jika perlu. Seterusnya, 41 orang responden iaitu $33.33 \%$ adalah masih rendah terhadap kebergantungan kepada dadah, responden masih ada sedikit perasaan untuk bergantung semula kepada dadah. Jumlah peratusan responden ini menunjukkan responden perlu diberikan kaunseling dan sokongan secara berterusan untuk bebas daripada bergantung kepada dadah. Sebanyak $4.07 \%$ iaitu 5 responden kajian berada di peringkat sederhana membuktikan bahawa responden tidak dapat melupakan dadah dan masih ingin bergantung kepada dadah. Oleh itu, pada peringkat ini responden kajian perlu diberikan kaunseling dan rawatan pemulihan secara berterusan untuk bebas daripada bergantung kepada dadah. Manakala peratusan terendah iaitu $2.44 \%$ bersamaan 3 responden kajian tahap kebergantungan kepada dadah adalah tinggi, responden tidak dapat melupakan dadah sepenuhnya dan akan bergantung semula kepada dadah selepas rawatan. 
Seterusnya, komponen kemungkinan relaps dadah membuktikan bahawa seramai 76 responden kajian atau $61.78 \%$ adalah tidak relaps kepada dadah dan responden kajian tidak mempunyai tanda-tanda relaps kepada dadah. Ini menunjukkan bahawa responden ini diberi kaunseling jika perlu sahaja berbanding dengan responden-responden yang lain. Seterusnya, 32 orang responden kajian iaitu sebanyak $26.02 \%$ adalah masih di peringkat rendah yang mana responden dijangka sedikit relaps kepada dadah. Jumlah peratusan responden ini perlu diberikan kaunseling dan sokongan secara berterusan untuk tidak relaps kepada dadah. Sebanyak $8.13 \%$ iaitu 10 responden kajian berada di peringkat sederhana relaps kepada dadah dan responden tidak dapat melupakan dadah serta masih ingin relaps kepada dadah pada peringkat ini. Oleh itu, responden kajian ini perlu diberikan kaunseling dan rawatan pemulihan secara berterusan daripada relaps kepada dadah. Manakala peratusan terendah iaitu $4.07 \%$ bersamaan 5 responden kajian tahap relaps kepada dadah adalah tinggi, responden tidak dapat melupakan dadah sepenuhnya dan akan relaps semula kepada dadah selepas rawatan. Pada peringkat ini klien masih lagi perlu diberikan perhatian dan rawatan secara berterusan untuk bebas daripada relaps kepada dadah.

Seramai 68 orang responden kajian atau 55. 28\% adalah baik dan responden mempunyai resiliensi yang baik kepada dadah. Ini menunjukkan bahawa responden ini diberi kaunseling jika perlu berbanding dengan responden-responden yang lain. Seterusnya, 42 orang responden kajian iaitu sebanyak $34.15 \%$ adalah masih rendah dalam daya tahan kepada dadah dan menjelaskan bahawa responden mempunyai resiliensi kurang terhadap dadah. Jumlah peratusan responden ini perlu diberikan kaunseling dan sokongan secara berterusan untuk tidak kembali kepada dadah. Sebanyak $7.32 \%$ iaitu 9 responden kajian berada di peringkat sederhana mempunyai daya tahan atau resilian yang lemah dan masih ingin kepada dadah. Responden kajian perlu diberikan kaunseling dan rawatan pemulihan secara berterusan daripada kembali kepada dadah. Manakala peratusan terendah iaitu 3.25 $\%$ bersamaan 4 responden kajian tahap resiliensi kepada dadah adalah tinggi, responden masih lagi perlu diberikan perhatian dan rawatan secara berterusan untuk bebas daripada dadah.

Seramai 61 orang responden kajian atau $49.59 \%$ adalah mempunyai kekuatan mental pada tahap yang baik. Responden mempunyai kekuatan mental yang baik dan dapat bertahan daripada dadah. Responden dapat dibebaskan pada peringkat ini. Seterusnya, 40 orang responden kajian iaitu sebanyak $32.52 \%$ adalah masih rendah klien tidak mempunyai kekuatan mental sepenuhnya dan masih mengingati dadah. Jumlah peratusan responden ini perlu diberikan kaunseling dan sokongan secara berterusan untuk tidak mengingati dadah. Sebanyak $14.63 \%$ iaitu 18 responden kajian berada di peringkat sederhana responden mempunyai kekuatan mental yang lemah dan masih ingin kepada dadah pada peringkat ini. Oleh itu, responden kajian ini perlu diberikan kaunseling dan rawatan pemulihan secara berterusan untuk bebas daripada bergantung kepada dadah. Manakala peratusan terendah iaitu $3.25 \%$ bersamaan 4 responden kajian, responden mempunyai kekuatan mental yang sangat lemah dan akan kembali semula kepada dadah selepas rawatan. Pada peringkat ini responden masih lagi perlu diberikan perhatian dan rawatan secara berterusan untuk bebas daripada dadah.

Hasil kajian mendapati bahawa seramai 64 responden kajian bersamaan $52.03 \%$ dibebaskan sepenuhnya dari CCRC. Responden kajian telah bebas daripada dadah dan boleh kembali ke pangkuan masyarakat serta menjalani kehidupan secara normal. Seterusnya, seramai 45 orang responden kajian dibebaskan sebagai pesakit luar bersamaan 36.59\%. Mereka ini boleh menerima rawatan sebagai pesakit luar di Klinik Cure \& Care , CCSC, CCH, Baitul Islah, PKI dan Rumah Persaraan untuk membantu penagih dadah kembali pulih. Sebanyak $8.94 \%$ iaitu bersamaan 11 responden kajian tidak boleh dibebaskan dan perlu diberikan pemantauan. Manakala peratusan terendah iaitu $2.44 \%$ bersamaan 3 responden kajian tidak boleh dibebaskan dan perlu menjalani rawatan secara intensif.

Secara keseluruhannya, kajian ini membuktikan bahawa berdasarkan kepada kerangka konseptual yang dibentuk dan diolah daripada kajian-kajian lepas berkaitan dengan empat komponen tersebut telah dibangunkan dan dinamakan instrumen Ujian Kepulihan Penagihan Dadah (DART) dan disahkan secara psikometri. Di samping itu, ia telah memperlihatkan secara praktikalnya kajian ini menggunakan FA untuk mendedahkan signifikan item melibatkan komponen dan sub komponen kepulihan penagihan dadah. Di samping itu, ini adalah alat yang dikembangkan sendiri dan 
dibangkitkan melalui definisi secara mendalam daripada kajian-kajian lepas oleh pengkaji sebelum ini dalam bidang psikologi.

\section{Kesimpulan}

Seperti yang telah disebutkan sebelumnya, beberapa komponen yang telah dibincangkan relevan untuk menjadi peramal pemulihan ketagihan dadah. Sementara itu, aspek-aspek ini juga boleh menyebabkan pemulihan ketagihan dadah. Oleh itu, untuk penyelidikan yang akan datang, penyelidik ingin mengkaji lebih lanjut mengenai bagaimana mendidik penagih tentang pemulihan ketagihan dadah dan melakukan amalan dan aktiviti yang baik dalam kehidupan seharian mereka sehingga mereka dapat mencapai pemulihan ketagihan dadah sepanjang hidup mereka. dengan pembinaan instrumen ini dapat membantu mengenal pasti tahap pemulihan penagih dadah pada peringkat awal agar dapat menyediakan program yang sesuai untuk pemulihan ketagihan dengan lebih tepat berdasarkan instrumen ini yang dibina oleh penyelidik. Kajian ini juga untuk memilih ketepatan faktor untuk mengukur tahap pemulihan ketagihan dadah itu sendiri dengan lebih mendalam berdasarkan psikologi pengukuran dalaman manusia sebagai penagih. Kajian ini juga merupakan kajian baru yang belum diterokai dalam kajian lepas yang melibatkan pemulihan konteks di Malaysia. Oleh itu, kajian ini memberi manfaat kepada agensi kerajaan dan bukan kerajaan dan juga digunakan sebagai penyelesaian yang baik untuk masalah pemulihan dadah di Malaysia.

\section{Rujukan}

AADK. (2015). Maklumat dadah 2015, Kementerian Dalam Negeri.

Anthony, W.A. (1993). Recovery from Mental Illness: The Guiding Vision of the Mental Health System in the 1990s. Innovations and Research, 2, 17-24.

American Psychiatric Association. (1994). Diagnostic and Statistical Manual of Mental Disorders (4th ed.). Washington DC: American Psychiatric Association.

Buckingham, M., \& Clifton, D. O. (2001). Now, discover your strengths. New York: Free Press.

Coopersmith. (2002). The Antecedent of Self Esteem. San Fransisco: W. H. Freeman \& Company.

Connor, K. M., \& Davidson, J. R. (2003). Development of a new resilience scale: The ConnorDavidson Resilience Scale (CDRISC). Depression and Anxiety, 18: 76-82.

C. K. Cheung, T. Y. Lee, C. M. Lee. (2003). Factors in successful relapse prevention among Hong Kong drug addicts. Treating Substance Abusers in Correctional Context: New Understanding, New Modalities From http://www.HaworthPress.com.

Deegan, P.E. (1988). Recovery: The Lived Experience of Rehabilitation. Psychiatric Rehabilitation Journal, 11:1119.

De-Micheli, D. \& Formigoni, M. L. (2000). Screening of Drug Use in a Teenage Brazilian Sample Using the Drug Use Screening Inventory. Addictive Behavior, 25(5): 683691.

Fauziah. I, Ezarina. Z, Mohd Norahim. M, S. Nor Jana, Saim, \& Salina, N. (2017). Self-esteem among former drug addicts under observation in malaysia: towards a comprehensive recovery. Jurnal Psikologi Malaysia, 31 (1) (2017): 29 - 39.

Fauziah, I, Ezarina, Z, Salina, N, Norulhuda, S, \& Nazirah, H. (2018). Pengaruh Gangguan Emosi Dalam Kalangan Orang Kena Pengawasan (Influence of Emotional Disturbance among Individuals under Surveillance. Jurnal Psikologi Malaysia 32 (4): 159-171

Fauziah, I., Bahaman, A. S., Mansor A.T., \& Mohamad Shatar, S. (2009). Faktor Menyumbang Kepada Penagihan Relaps dalam Kalangan Penagih Dadah PUSPEN di Semenanjung Malaysia. Jurnal Agensi AntiDadah Kebangsaan, 5:235-251.

Fernandez-Hermida, J. R., Secades-Villa, R., FernandezLudena, J.J., dan Marina-Gonzalez, P. A. (2002). Effectiveness of a therapeutic community treatment in Spain: A long-term follow up study. Eropean Addiction Research, 8, 22-29.

Glantz, M. D., \& Johnson, J. L. (1999). Resilience and Development: Positive Life Adaptations. New York: Kluwer Academik/Plenum Publishers.

Hammer-bacher, M. \& Lyvers, M. (2006). Factors associated with relapse among clients in Australian substance disorder treatment facilities. Journal of Substance Use, 11 (6), 387-394. 
Krosnick, J. A., \& Presser S. (2010). Question and Questionnaire Design.

Lasimon Matokrem. (2007). Intervensi dan peranan kaunselor untuk menjana kepulihan klien sepanjang hayat. Jurnal Anti Dadah Malaysia, 1(1), 97-118.

Leventhal, A.M., Kahler, C.W., Ray, L.A., Stone, K., Young, D., Chelminski, I., \& Zimmerman, M. (2008). Anhedonia and Amotivation in Psychiatric Outpatients with Fully Remitted Stimulant Use Disorder. American Journal on Addictions, 17, 218 -22.

Lent, R. W. (2004). Toward a Unifying Theoretical and Practical Perspective on Well-Being and Psychosocial Adjustment. Journal of Counselling Psychology, 51(4), 482-509.

Lily, Mastura, H. \& Ooi Boon Keat. (2004). Penerokaan gaya hidup penagih dadah: Perspektif teori psikologi individu. Pertanika Journal of Social Sciences \& Humanities, 12(20): 11.

Lozano, B. E., Stephens, R. S., dan Roffman, R. A. (2006). Addiction, 101, 1589-1597.

Matokrem, L. (2007). Intervensi dan Peranan Kaunselor untuk Menjana Kepulihan Klien Sepanjang Hayat. Jurnal Antidadah Malaysia, 1.

Melemis S.M. (2015). Relapse prevention and the five rulesb of recovery. YALE Journal of Biology and Medicine, 88, 325-332.

Mental Health Advocacy Coalition. (2008). Destination: Recovery. Auckland: Mental Health. Foundation of New Zealand.

Miller, A. F. (2001). Substance Abuse Treatment for Women with Children. Corrections Today, 61: 88-92.

Mohamed. (2006). Mencegah, merawat dan memulihkan penagihan dadah: beberapa pendekatan dan amalan di Malaysia. Kuala Lumpur: Utusan Publications \& Distributors Sdn.

Moody, Melissa L. (2003). Factors Influencing Substance Abuse/Dependence and Treatment Outcome of Adolescents in a Residential Substance Abuse Program: An Exploratory Study. Masters Theses. 1503.

N. M. Mahmood. (1995) Perubahan Psikologikal dari segi harga diri, profil personality dan penggunaan mekanisme bela diri di kalangan penagih yang mengikuti pemulihan serenti, Universiti Kebangsaan Malaysia, Bangi

Peterson, C., \& Seligman, M. E. P. (2004). Character strengths and virtues: A handbook and classification. American Psychological Association; Oxford University Press.

Rico, E. D., Dios, H. C., Ruch, W. (2012). Content validity evidences in test development: An applied perspective. International journal of clinical and health psychology, 12(3), 449-460.

Rosenberg, M. (1965). Society and the Adolescent Self Image. Princeton, NJ: Princeton University Press.

Rovee-Collier, C. (1999). The development of infant memory. Current Directions in Psychological Science, 8(3), 80-85.

Rowley, J. (2014). Designing and using research questionnaires. Management Research Review, 37(3), 308-330.

Ruhani, M. M., Abdullah, M., \& Nor Ezdianie, O. (2012). Keperibadian dan sokongan sosial penghuni PUSPEN: Implikasi terhadap program pemulihan. Journal Kemanusiaan, 20(1): 56-66.

Rutter, M. (1965). Resilience in the face of adversity. Protective factors and resistance to psychiatric disorder. BrJPsychiatry.1985, 147:598-611.

Scozelli, J. (1987). Drugs Abuse: Preventions and Rehabilitations in Malaysia. Bangi: Universiti Kebangsaan Malaysia.

Sharma, 0. P. (1995). The dilemma of addictive personality and resolvability of drug dependence. Journal of Indian Psychology, 13(1), 47-50.

Sousa, L., \& Lyubomirsky, S. (2001). Life satisfaction. In J. Worell (Ed.), Encyclopaedia of women and gender: Sex similarities and differences and the impact of society on gender. San Diego, CA: Academic Press

Sun, A. P. (2007). Relapse among substance-abusing women: Components and processes. Substance Use and Misuse, 42, 1-21.

Werner, E., \& Smith, R. (1982). Vulnerable but invincible: A longitudinal study of resilient children and youth. New York: Adams, Bannister and Cox.

WHO. (1964). Scientific Group on the Evaluation of Dependence Producing Drugs Wld Hlth Org. techn. Rep. Ser., 287. 